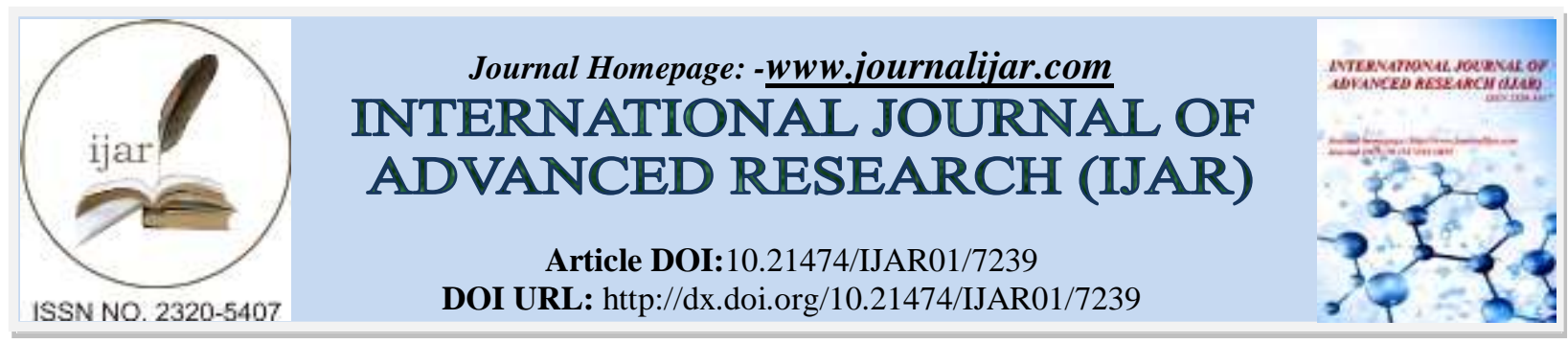

RESEARCH ARTICLE

\title{
A STUDY OF THE WOMEN WORKFORCE IN A WEAVING VILLAGE OF ASSAM.
}

Parmita Khakhlari.

Research Scholar, Department of Sociology, Dibrugarh University.

\section{Manuscript Info}

Manuscript History

Received: 09 April 2018

Final Accepted: 11 May 2018

Published: June 2018

Keywords:-

women weavers, workforce, silk

weaving industry, development.

\begin{abstract}
The handloom weaving sector has been one of the most traditional cottage industries and has been the mainstay of rural industrialisation in India and one of the largest industries where women workers depend heavily for livelihood both in rural and urban areas. This handloom weaving still continues alongside the most modern textile machinery in India.

The present paper is an attempt to study the gender perspective focussing on the social and economic life of the women weavers working in the age-old weaving sector of Sualkuchi which is in the Kamrup district of Assam. The study also analyses the problems that deprive women workers involved in the weaving industry of Sualkuchi. A sample of 100 women weavers- both independent weavers and those working for master weavers and owners of loom were selected for the study through purposive sampling and the respondents were administered by interview schedule.

Throughout a long period of the handloom industry, women working force has been crucial in sustaining this traditional industrial sector through centuries. There is a need to understand the current scenario of this weaving and manufacturing industry and its impact on women's wage, employment opportunities and development.
\end{abstract}

Copy Right, IJAR, 2018,. All rights reserved.

\section{Introduction:-}

Women participate in almost every industrial sector. In the wake of industrialization, power looms and mill made totally deteriorated the overall status of handlooms and its weavers. Mainly it is seen burdening the life of women, a major workforce in the handloom sector. Women used to prefer weaving as profession which they may think safe and secure though it is a restless activity and not considered much of a profitable occupation. In Assam, the age old association of women with the weaving industry is considered an important qualification of the girl for marriage. Female work participation has increased in most of the North Eastern states of India. The Ninth Five Year Plan commits to empower women through creating and enabling environment where women can freely exercise their right both within and outside their home, as equal partner along with men. The objective of the plan is to equip women with necessary skills in the modern upcoming trades which could keep them gainfully engaged besides making them economically independent and self-reliant; and to increase access to credit through setting up of a 'Development Bank for Women Entrepreneurs' in small and tiny sectors. The Census of India, 2011 reveals that $25.5 \%$ women in India have participated in the workforce. The women participation rate is higher in the 8 states of Northeast India i.e. $26.1 \%$ and that of Assam is $22.5 \%$. However majority of the women working in cottage and small scale industries are paid quite low. The handloom sector has been one of the most traditional cottage industries 
and has been the mainstay of rural industrialisation in India and one of the largest industries where women workers depend heavily for livelihood both in rural and urban areas. This handloom weaving still continues alongside the most modern textile machinery in India.

\section{Women weavers of Assam:-}

Since ancient times Assam was well known for her silk production. The production of silk fabrics continued to be a home industry. "In the context of silk weaving in Assam, Sualkuchi is a name that stands apart. Weaving tradition can be traced back to $11^{\text {th }}$ century when King Dharampal of the Pala Dynasty sponsored the craft and brought 26 weaving families from Tantikuchi to Sualkuchi. The hamlet developed into a weaving village only after the Ahoms occupied Sualkuchi, defeating Mughals in mid $17^{\text {th }} \mathrm{C}$. Weaving has since thrived in Sualkuchi earning it the sobriquet, 'Manchester of the East'. It has now become a way of life in Sualkuchi, and a home without loom here is beyond imagination" (SIRD, 2007).

Modernisation as it came to Assam's weaving industry was a limited process. Some of the weaver respondents told that their family has been in the silk manufacturing business since 1965. Consumerism and increased demand in its wake did manage to change the traditional economy in a material way. Families which perhaps till then were mostly producing for domestic consumption now began investing their resources in setting up more looms to cater to commercial demand. Commercialisation meant that there was now an increased demand of labour such as weavers, spinners, helpers etc. as the labour of the women folk in the household was no longer enough to operate the looms. For women, their traditional role in the economy slowly became redundant. Most of the women are economically disadvantaged and do not have any means of livelihood apart from a few jobs in agriculture. The occupation of weaving is considered ideal for the women folks as it is physically safe and less stressful. The art of weaving also brings aesthetic pleasure to these women.

\section{Women as marginalised group:-}

People who are marginalised have little control over their lives and the resources available to them. As the objective of development is to create an enabling environment for people to enjoy a productive, healthy and creative life, it is important to address the issue of marginalisation. It is a complex problem and there are many factors that cause marginalisation. This paper deals with the problems associated with the women weavers suffering from marginalisation and the ways to reduce them. Under different conditions marginalisation is one of the manifestations of gender inequality. Women belonging to lower classes, lower castes, illiterate and the poorest region have different levels of marginalisation than their better off counter parts. According to Adriana Mata Greenwood, a Statistician in ILO explains that to serve users, labour statistics need to reflect reality as closely as possible. She further says, "Since statistical categories reflect what are perceived to be "core" employment situations, in which men dominate and women are found to be in "other" work situations, the neglect of women's work is precarious. The systemic underreporting and misinterpretation of women's contribution to the economy perpetuate a vicious circle of inequality between men and women".

"In the case of Sualkuchi this contention become very relevant, because the failure to acknowledge women as contributors to the silk industry means that there is no policy in place for them. What is further concern is that although women's labour in reeling, spinning is vital in silk production, these tasks are not neutral: they are hierchical and confine women to a subordinate position" (Bhattacharjee, 2010).

\section{Empowering women through weaving:-}

In the $20^{\text {th }}$ century women have reclaimed weaving as an art. According to the 2013 handloom census, women weavers in India today number over 38 million. Most belongs to traditional families of weavers, and ever since they were young girls, have been handling most of the pre-weaving work such as preparation of the yarn and the looms, dying yarn and fabric. Women even sit at the loom and do the actual weaving. There has been a constant deskilling of women weavers with long professional backgrounds has enslaved them to longer work hours. As mentioned by historical sources, there is bent towards more female participation in the process as compared to males. "Most women are literate and education is one of the motivations for these women to make independent decisions including taking weaving as a profession" (Kalita, 2009).

The empowerment of women is crucial for development of any nation. Women today are seen to share equal status as men. The day to day challenges that the women are still forced to face makes women's empowerment one of the top priorities of any civilised society. All women should be encouraged by the vision of economic independence 
and a society devoid of gender bias. The most popular means of livelihood among underprivileged women is weaving, handicrafts or working in any cottage based industry. Women are ideal to contribute to this industry because of their strong aesthetic sense, hard working nature and inclination towards art. Women weavers not only act as the main workforce behind the textile industry, they also keep the ancient and traditional forms of art alive through their diverse artistry. These women also contribute in keeping alive the cottage industries that increase employment and also ensure betterment of society. As for the area of study which is Sualkuchi it was found that the association between women and silk industry in the region is age old. Women perform major role in the industry at different stages, as said by Goswami in his work in 2005. The factory has become more than just workplace but a socio-cultural environment of interaction between peers and as much as the loom has become an icon of empowerment.

\section{The field and the Analysis:- \\ Methodology:-}

Our study is set in the silk weaving centre of Sualkuchi where silk manufacturing is a way of life for most of the population mostly the women folk. The study focuses on the participation and role played by women in handloom sector. Handloom weaving is a sector where women appear to have traditionally played a very important role. The weaving or sericulture sector is very much dependent on women's labour and the traditional skills that went with it.

The respondents for the present study are the women weavers in Sualkuchi and Government officials. Primary data of 100 respondents were interviewed. The respondents were selected using purposive sampling and were administered with interview schedule. Apart from backgrounds of the respondents, the study also collected information on the social life of the weavers. The perceptions of the women master weavers and paid weavers on their working status and living condition were also collected.

In addition to weavers as respondents to the study, 10 Government officials under Central and State Government were also selected. Secondary data are from Government reports of the Government organizations i.e. the Handloom and Textile Department, Ambari, Guwahati; Central Silk Board, Regional Office, Guwahati and the Regional Silk Technological Research Station, Guwahati along with relevant books, publications in newspapers and journals.

\section{Migratory status:-}

Table 1:-Distribution by migratory status of Respondents

\begin{tabular}{|l|l|l|l|}
\hline S1 No. & Status & Wage weavers \\
\cline { 3 - 4 } & & No. & $\%$ \\
\hline 1 & Migrated from nearby areas/districts & 65 & 65 \\
\hline 2 & Non migrated & 35 & 35 \\
\hline & Total & 100 & 100 \\
\hline
\end{tabular}

The weavers in Sualkuchi comprises of hired migratory young women, mostly from the nearby areas and from other districts of Assam, seeking employment in Sualkuchi to earn a living. The table 1 shows that $65 \%$ of the weavers interviewed are migrated to the weaving village. In fact it is found that the migrant weavers are dominating over the local ones and the women weavers outnumber male weavers.

Working status:-

Table 2:-Distribution by workers working

\begin{tabular}{|l|l|l|l|}
\hline S1 No. & Category & Respondents \\
\cline { 3 - 4 } & & No. & $\%$ \\
\hline 1 & Independent worker (master weaver) & 7 & 7 \\
\hline 2 & Working under master weaver (paid weaver) & 85 & 85 \\
\hline 3 & Co operatives society & 8 & 8 \\
\hline 4 & Other & 0 & 0 \\
\hline & Total & 100 & 100 \\
\hline
\end{tabular}

The study reveals that in case of Sualkuchi, despite their skill in silk processing and weaving, very few women are entrepreneurs or master weavers themselves. Only $7 \%$ women master weavers were found in this part of region. $85 \%$ were paid workers from within and outside Sualkuchi and $8 \%$ work under Cooperative societies as shown in 
table 2. The respondents who are master weavers reveal that both sons and daughters knew weaving; the sons preferred working outside the home, looking after marketing of the products. Daughters continue to work in looms if hired workers are on leave or when there is increase in demand during festive seasons.

It was found that $65 \%$ of the weavers are migrants from nearby districts. Lack of employment opportunity at their place of origin compelled them to migrate to Sualkuchi. Half of women weavers belong to the age group of 20-32 years and $68 \%$ of the weavers are unmarried and $32 \%$ are married.

When interviewed it was found that almost $61 \%$ of the women weavers have passed primary level education, $34 \%$ secondary level and only $5 \%$ has attended college education. Most of them deprived of school education due to poor economic condition.

It is believed that workers are the driving force behind a nation's development. In reality, worker's daily lives reflect poor economic conditions and a low social status. The study suggests that both married and single female workers migrated into the silk industrial village in order to fulfil duties towards their family and to earn something before they get married and then return to their own villages after their wedding. These weavers, mostly women, and often poorly paid. Under the Indian Constitution Clause (d) of Article 39 which is a part of Directive principles of state policy provides 'equal pay for equal work' for both men and women'. The low wages and poor living conditions discourage weavers from staying on in Sualkuchi for long periods.

The weaving centres are engaged by both male and female weavers. As per the male-female participation rate in weaving is concerned, in Sualkuchi, where the commercial weaving centres are highly concentrated, it is found more or less equal i.e. $48 \%$ are male weavers and $52 \%$ are female weavers. Both men and women perform a major role in the industry at different stages. The weavers did not take any formal training for learning the production process. The paid weavers are not provided training in any training centres and because of this they are not capable to weave complex designs as per demand of the modern market. Some women weavers are even willing to switch to other jobs if better prospect is provided. They work for more than 12 hours which is a time beyond regular work hours.

Economic conditions of the weaver's families were found to be not so satisfactory. More than $75 \%$ of hired women weavers earn between 3000-6000 per month only on the basis of per meter per design. Some of the weavers believe that they would like their children to go and work somewhere else rather than handloom weaving. Weaving industry may introduce changes in the life of the weavers; it is expected to increase income to a point above subsistence level and also to promote a rise in level of living.

The weavers are mostly paid on weekly or monthly payment system and most of them receive advance payment from the employers if necessity arises

The quality of work sheds and living spaces is found to be not so healthy and hygienic. There is a possibility of health problems due to constant strain on the weaver's body from the long working hours.

The government claims to have launched many schemes for the weaver's development and upliftment. But in actual practice hardly any of these measures has proved to be beneficial to the weavers.

\section{Conclusion:-}

Women have always played an important role in the socio economic development of the society since ancient times. Women in North East India, particularly Assam enjoys a comparatively higher status in society. Even though there are many schemes to promote silk industry in the state, however this does not in any way seem to have worked well for the industry or the vast number of weavers involved in it. In fact, women of Sualkuchi are practically out of the direct focus of developmental programmes. Weaving not only offer alternatives, by not only enhancing the traditional craft making skill of women with safe access to product and small business development, marketing skills and empowering women artisans to possess appropriate tools to fight against marginalisation, poverty and gender discrimination. By providing marketing support, Government aid and basic training facilities these women weavers will be able to earn a living using their traditional skills. 


\section{References:-}

1. Assam Handloom: From the SIRD, Assam's Perspective, A Study of Self Employment Projects, Govt. of Assam. (2007). Gauhati India, Nanda Talukdar foundation.

2. Bhattacharjee, Mahua. (2010). Silken Hues, Muted Voices: Women in the Silk Industry of Assam. Panbazar, Guwahati: DVS Publishers.

3. Goswami, Kishore. (2005). Impact of Globalisation of Silk Industry in North east India: An Assessment from gender Perspective. ICFAI University Press, India, ISBN: 978-81-314-2482-7, pp: 193-210.

4. Greenwood, Adriana Mata. (2008). Gender Issues in Labour Statistics. International Labour Review, Vol 138 (1999) No.3

5. Report of Assistant Directorate of Handloom \& Textile Department, Guwahati, Assam.

6. Reports of Central Silk Board (2013-2014), Ministry of Textiles- Government of India.

7. KalitaNiharRanjan. (2009). Entreprerenual Motivation in Cottage Industry - A Case study in the Silk Industry of Assam, Proceeding of International Entreprenuership Congress, Izmir University of Economics, ISBN: 978975-8789-37-0. 